\title{
Self-control profile of students in implementing discipline in school
}

\author{
Nur Damayanti ${ }^{1} \&$ Asmidir Ilyas ${ }^{2}$ \\ ${ }^{12}$ Universitas Negeri Padang
}

\begin{abstract}
Abtract
Discipline is the most important thing for students to succeed in learning. Therefore, students are expected to have high self-control in order to avoid negative behavior. The purpose of this study was to describe behavioral control, cognitive control and decision control of students in carrying out discipline. This research is a descriptive study, the entire population of students of class X and XI in SMKN 1 Kotanopan and as many as 260 samples obtained by 158 students. This research instrument was a questionnaire. Research findings reveal student's self-control in carrying out discipline in SMKN 1 Kotanopan been good. Suggested to the Guidance and Counseling teacher to provide service and develop programs to improve student's self-control.
\end{abstract}

Keywords: Self Control, Discipline

This is an open access article distributed under the Creative Commons Attribution License, which permits unrestricted use,
distribution, and reproduction in any medium, provided the original work is properly cited. (C2018 by author

\section{PENDAHULUAN}

Disiplin merupakan hal yang sangat penting agar siswa tertib dan teratur dalam belajar di sekolah. Disiplin yang ada di sekolah akan membantu siswa memperoleh suasana dan pembelajaran yang baik sehingga dapat mengantarkannya kepada kesuksesan dalam hasil belajar. Menurut Zulkarnain (2002) remaja yang disiplin akan memiliki etos kerja tinggi serta tanggung jawab dan komitmen yang kuat, yang pada akhirnya akan mengantarkan remaja menjadi sumber daya manusia yang berkualitas. Disiplin merupakan suatu aturan pendidikan. Menurut Sofan Amri (2013) disiplin adalah sikap seseorang yang menunjukkan ketaatan atau kepatuhan terhadap peraturan atau tata tertib yang telah ada yang dilakukan dengan senang hati dan kesadaran diri. Hal senada juga disampaikan oleh Soejitni Irmin dan Abdul Rochim (2004) disiplin dapat dimaknai sebagai kepatuhan pada peraturan baik lisan maupun tulisan.

Salah satu faktor yang mempengaruhi keberhasilan siswa dalam melaksanakan disiplin di sekolah adalah adanya pengendalian diri. Menurut Syamsul Bachri Thalib (2010) kontrol diri merupakan kemampuan individu untuk mengendalikan dorongan-dorongan, baik dari dalam diri maupun dari luar diri individu. Selanjtnya, Gorton (dalam Bernardus Widodo, 2013) mengklasifikasikan bentuk-bentuk perilaku pelanggaran disiplin sebagai akibat dari rendahnya tingkat kontrol diri siswa, yaitu: (1) perilaku tidak sesuai yang dilakukan siswa dalam kelas berupa tindakan membantah atau menjawab kata-kata guru dengan kasar, tidak memperhatikan penjelasan guru, mengganggu teman lain, melakukan perusakan, mengucapkan kata-kata kotor, menyontek dan menyerang teman, (2) perilaku tidak sesuai yang dilakukan di luar kelas, meliputi berkelahi, merokok, mengkonsumsi obat-obat terlarang, mencuri, berjudi, membuang sampah sembarangan, melakukan tindakan yang digerakkan sesorang, misalnya demonstrasi, berada di tempat-tempat terlarang di sekolah, misalnya bermain-main di laboratorium, (3) membolos, (4) terlambat, berupa terlambat hadir di kelas atau sekolah. Hal ini mengisyaratkan bahwa kontrol diri disinyalir memiliki kontribusi dalam menciptakan suatu model perilaku disiplin.

Berdasarkan hasil pengamatan dan hasil wawancara pada tanggal 28 September-03 Oktober 2018 dengan lima belas orang siswa, tiga orang guru BK dan dua orang guru mata pelajaran, ternyata masih ada siswa yang 
masih melanggar disiplin di sekolah, seperti terlambat datang ke sekolah, keluar sekolah tanpa izi pada saat jam pelajran berlangsung, menyontek, tidak memakai atribut sekolah dengan lengkap, memakai handphone, merokok di lingkungan sekolah, tidak mengerjakan PR serta tidak masuk sekolah tanpa izin. Kondisi ini jika tidak ditanggapi dengan serius maka akan berdampak buruk, kebiasaan melaksanakan disiplin harus ditanamkan semenjak dini.

\section{METODOLOGI PENELITIAN}

Penelitian ini menggunakan metode kuantitatif dengan pendekatan analisis deskriptif. Populasi penelitian adalah siswa kelas X dan XI dengan jumlah 260 orang. Sampel penelitian terdiri dari 158 orang siswa SMK N 1 Kotanopan menggunakan teknik simple random sampling. Alat pengumpulan data menggunakan angket yang jumlah 36 item angket tertutup dengan model skala Likert. Pilihan jawaban menggunakan skala Likert, dengan alternatif jawaban yaitu: (1) SL, (2) SR, (3) KD, (4) JR, dan (5) TP. Pernyataan angket dalam bentuk positif dan negatif. Data di analisis dengan teknik statistik yaitu teknik persentase menggunakan rumus yang dikemukakan oleh Nana Sudjana (2001), yaitu:

$$
\begin{array}{cl}
\mathrm{P}= & \frac{f}{n} \times 100 \\
\text { Keterangan : } & \\
\mathrm{P} \quad=\text { Tingkat persentase jawaban } \\
\mathrm{f} \quad=\text { Frekuensi jawaban } \\
\mathrm{n} \quad=\text { Jumlah responden }
\end{array}
$$

\section{HASIL PENELITIAN}

Hasil penelitian secara keseluruhan gambaran kontrol diri siswa dalam melaksanakan disiplin di sekolah

\begin{tabular}{|c|c|c|c|c|c|c|c|c|c|c|c|}
\hline \multirow{3}{*}{ No. } & \multirow{3}{*}{ Sub Variabel } & \multicolumn{10}{|c|}{ Kategori } \\
\hline & & \multicolumn{2}{|c|}{ SB } & \multicolumn{2}{|c|}{$\mathbf{B}$} & \multicolumn{2}{|c|}{ CB } & \multicolumn{2}{|c|}{ KB } & \multicolumn{2}{|c|}{ TB } \\
\hline & & $\mathrm{f}$ & $\%$ & $\mathrm{f}$ & $\%$ & $\mathrm{f}$ & $\%$ & $\mathrm{f}$ & $\%$ & $\mathrm{f}$ & $\%$ \\
\hline 1. & Keseluruhan & 8 & 5,1 & 48 & 30,4 & 47 & 29,7 & 53 & 33,5 & 2 & 1,3 \\
\hline \multirow[t]{3}{*}{2.} & Kontrol perilaku & 9 & 5,7 & 42 & 26,6 & 69 & 43,7 & 29 & 18,3 & 9 & 5,7 \\
\hline & $\begin{array}{l}\text { a. Kemampuan } \\
\text { mengatur } \\
\text { pelaksanaan }\end{array}$ & 0 & - & 64 & 40,5 & 66 & 41,7 & 14 & 8,9 & 14 & 8,9 \\
\hline & $\begin{array}{l}\text { b. Kemampuan } \\
\text { mengatur stimulus }\end{array}$ & 13 & 8,2 & 41 & 26 & 56 & 35,4 & 31 & 19,6 & 17 & 10.8 \\
\hline \multirow[t]{3}{*}{3.} & Kontrol kognitif & 9 & 5,7 & 45 & 28,5 & 57 & 36,1 & 33 & 20,9 & 14 & 8,8 \\
\hline & $\begin{array}{l}\text { a. Kemampuan } \\
\text { memperoleh } \\
\text { informasi }\end{array}$ & 6 & 3,8 & 52 & 32,9 & 60 & 38 & 29 & 18,3 & 11 & 7 \\
\hline & $\begin{array}{l}\text { b. Kemampuan } \\
\text { melakukan } \\
\text { penilaian }\end{array}$ & 0 & - & 59 & 37,3 & 56 & 35,5 & 28 & 17,7 & 15 & 9,5 \\
\hline \multirow[t]{2}{*}{4.} & Kontrol keputusan & 17 & 10,8 & 35 & 22,1 & 50 & 31,6 & 51 & 32,3 & 5 & 3,2 \\
\hline & $\begin{array}{l}\text { a. Kemampuan } \\
\text { mengambil } \\
\text { keputusan }\end{array}$ & 17 & 10,8 & 35 & 22,1 & 50 & 31,6 & 51 & 32,3 & 5 & 3,2 \\
\hline
\end{tabular}
dirangkum pada tabel berikut ini:

Tabel 1

Profil Kontrol Diri Siswa dalam Melaksanakan Disiplin di Sekolah $\mathbf{n}=\mathbf{1 5 8}$

Berdasarkan tabel 1 dapat dilihat kontrol diri siswa dalam melaksanakan disiplin di sekolah secara keseluruhan terdapat 5,1\% siswa berada pada kategori sangat baik dan 30,4\% siswa berada pada kategori baik, jika digabungkan maka terdapat 35,5\% siswa berada pada kategori sangat baik dan baik. Kemudian 29,7\% siswa berada pada kategori cukup baik. Sedangkan 33,5\% siswa berada pada kategori kurang baik dan 1,3\% siswa berada pada kategori tidak baik, jika digabungkan maka terdapat 34,8\% siswa berada pada kategori kurang baik 
dan tidak baik. Dapat disimpulkan bahwa gambaran kontrol diri siswa dalam melaksanakan disiplin di sekolah berada pada kategori sangat baik dan baik dengan persentase 35,5\%, namun angka ini harus ditingkatkan karena selisih antara persentase sangat baik dan baik dengan persentase kurang baik dan tidak baik hanya sedikit saja yaitu $0,7 \%$.

Pada kemampuan kontrol diri siswa dalam melaksanakan disiplin di sekolah berkaitan dengan aspek kemampuan mengontrol perilaku terdapat 5,7\% siswa berada pada kategori sangat baik dan 26,6\% siswa berada pada kategori baik, jika digabungkan maka terdapat 32,3\% siswa berada pada kategori sangat baik dan baik. Kemudian 43,7\% siswa berada pada kategori cukup baik. Sedangkan 18,3\% siswa berada pada kategori kurang baik dan 5,7\% siswa berada pada kategori tidak baik, jika digabungkan maka terdapat $24 \%$ siswa berada pada kategori kurang baik dan kategori tidak baik. Dapat disimpulkan bahwa sebagian besar siswa memiliki kontrol diri dalam melaksanakan disiplin di sekolah pada aspek kemampuan mengontrol perilaku berada pada kategori cukup baik dengan persentase $43,7 \%$.

Kemudian, kemampuan kontrol diri siswa dalam melaksanakan disiplin di sekolah berkaitan dengan aspek kemampuan mengontrol kognitif terdapat 5,7\% siswa berada pada kategori sangat baik dan 28,5\% siswa berada pada kategori baik, jika digabungkan maka terdapat 34,2\% siswa berada pada kategori sangat baik dan baik. Kemudian $36,1 \%$ siswa berada pada kategori cukup baik. Sedangkan 20,9\% siswa berada pada kategori kurang baik dan $8,8 \%$ siswa berada pada kategori tidak baik, jika digabungkan maka terdapat $29,7 \%$ siswa berada pada kategori kurang baik dan tidak baik. Dapat disimpulkan bahwa sebagian besar siswa memiliki kontrol diri dalam melaksanakan disiplin di sekolah pada aspek kemampuan mengontrol kognitif berada pada kategori cukup baik dengan persentase $36,1 \%$.

Selanjutnya, kemampuan kontrol diri siswa dalam melaksanakan disiplin di sekolah berkaitan dengan aspek kemampuan mengontrol keputusan terdapat 10,8\% siswa berada pada kategori sangat baik dan $22,1 \%$ siswa berada pada kategori baik, jika digabungkan maka terdapat 32,9\% siswa berada pada kategori sangat baik dan baik. Kemudian 31,6\% siswa berada pada kategori cukup baik. Sedangkan 32,3\% siswa berada pada kategori kurang baik dan 3,2\% siswa berada pada kategori tidak baik, jika digabungkan maka terdapat 35,5\% siswa berada pada kategori kurang baik dan tidak baik. Dapat disimpulkan bahwa sebagian besar siswa memiliki kontrol diri dalam melaksanakan disiplin di sekolah pada aspek kemampuan mengontrol keputusan berada pada kategori kurang baik dan tidak baik dengan persentase 35,5\%.

\section{PEMBAHASAN}

\section{Gambaran Kontrol Perilaku Siswa dalam Melaksanakan Disiplin di Sekolah}

Berdasarkan hasil pengolahan data, terungkap sebagian besar siswa memiliki kemampuan mengontrol perilaku dalam melaksanakan disiplin di sekolah tergolong pada kategori "cukup baik" dengan capaian responden $43,7 \%$.

Hasil tersebut menunjukkan bahwa pertama, kemampuan siswa untuk mengatur pelaksanaan disiplin di sekolah berada pada kategori cukup baik dengan capaian responden 41,7\%. Hal ini dapat dilihat ketika siswa dihadapkan pada situasi yang bisa mempengaruhi siswa untuk melanggar peraturan disiplin, seperti kondisi kelas yang kurang nyaman sehingga siswa tidak betah di dalam kelas atau tidak memakai seragam sekolah dengan ketentuan yang ada.Dari temuan penelitian ini, tidak semua siswa mampu mengontrol pelaksanaan disiplin dengan baik, karena pada kenyataannya sebagian siswa masih melaksanakan hal tersebut.

Kedua, dari hasil penelitian ini juga terungkap kemampuan siswa dalam mengatur stimulus yang tidak dikehendaki berada pada kategori cukup baik dengan capaian responden 35,4\%. Hal ini dapat dilihat dari hasil penelitian masih terdapat siswa yang mengikuti ajakan teman meribut di dalam kelas pada waktu belajar ataupun mengikuti ajakan teman untuk keluar kelas pada saat jam pelajaran berlangsung. Idealnya, ketika siswa diajak mengobrol di kelas oleh teman sedangkan guru sedang menerangkan pelajaran, ataupun ketika diajak keluar kelas oleh teman saat jam pelajaran berlangsung, siswa dengan kontrol diri yang baik akan mengetahui bagaimana cara menolak ajakan tersebut dengan baik, ataupun menghindari ajakan tersebut. Namun, jika kontrol diri siswa rendah akan terjadi hal sebaliknya. Ghufron, N.M. dan Risnawita, R. (2010) mengemukakan ketika individu tidak mampu menggunakan kemampuan dirinya untuk menentukan siapa yang mengendalikan situasi, maka sumber eksternal lah yang akan mengendalikan dirinya.

Dari hasil penelitian ini, tidak semua siswa mampu mengatur stimulus dengan semestinya. Meskipun demikian, sebagian siswa menunjukkan kemampuan mengatur stimulus dengan baik. Cara agar meningkatkan kontrol perilaku siswa yang sedang menjadi tinggi adalah dengan cara mencegah datangnya stimulus, menunda stimulus, serta menghentikan stimulus (Averill dalam Ghufron, N.M. dan Risnawati, R. (2010). Hal ini sejalan 
dengan pendapat Ghufron, N.M. dan Risnawita, R. (2010) ada beberapa cara untuk menghadapi stimulus yang tidak dikehendaki yaitu dengan mencegah atau menjauhi stimulus, menempatkan tenggang waktu di antara stimulus, menghentikan stimulus sebelum waktunya berakhir, dan membatasi intensitasnya.

Menurut Averill (dalam Sari, L., 2014) kontrol perilaku merupakan adanya kesiapan dan penggunaan tindakan yang dapat secara langsung mempengaruhi atau memodifikasi suatu keadaan yang tidak menyenangkan.

Individu yang memiliki kontrol perilaku yang tinggi akan mampu mengendalikan setiap tindakannya tanpa membutuhkan orang lain untuk menentukan setiap tindakannya dan mampu mengendalikan kapan suatu stimulusdan situasi tersebut diinginkannya serta bagaimana cara untuk mempersiapkan diri menghadapi stimulus tersebut.

Dengan demikian, kontrol perilaku siswa di SMK N 1 Kotanopan perlu ditingkatkan dari kategori cukup baik menjadi sangat baik. Peningkatan kontrol perilaku siswa dalam melaksanakan disiplin di sekolah dapat ditingkatkan melalui layanan bimbingan dan konseling.

\section{Gambaran Kontrol Kognitif Siswa dalam Melaksanakan Disiplin di Sekolah}

Berdasarkan hasil penelitian, terungkap sebagian besar siswa memiliki kemampuan mengontrol kognitif dalam melaksanakan disiplin di sekolah tergolong pada kategori "cukup baik" dengan capaian responden $36,1 \%$.

Hal tersebut menunjukkan pertama, kemampuan siswa untuk memperoleh informasi mengenai pelaksanaan disiplin berada pada kategori cukup baik dengan capaian responden $38 \%$. Hal ini berarti ketika siswa dihadapkan pada informasi yang kurang memadai mengenai disiplin di sekolah, maka siswa tersebut akan mencari informasi dari berbagai sumber terpercaya agar informasi yang didapatkan menjadi akurat. Seperti pada penelitian ini misalnya, ketika suatu hari siswa tidak berkesempatan hadir di sekolah, maka siswa tersebut akan mencari informasi tentang ketertinggalannya mengikuti pelajaran dengan bertanya kepada teman dan guru yang bersangkutan.

Namun pada kenyataannya, tidak semua siswa mampu melaksanakan hal tersebut, karena masih terdapat siswa yang kurang baik dalam hal memperoleh informasi. Meskipun demikian, temuan penelitian ini tidak bisa dipandang sebagai hal negatif karena pada kenyataannya, sebagian siswa mampu memperoleh informasi dengan baik, sebagaimana pendapat Ghufron, N.M. dan Risnawati, R. (2010) yaitu, kemampuan siswa mengantisipasi keadaan yang tidak menyenangkan dapat dilakukan dengan berbagai pertimbangan.

Kedua, dari hasil penelitian ini menunjukkan kemampuan siswa dalam melakukan penilaian terhadap disiplin di sekolah berada pada kategori baik dengan capaian responden 37,3\%. Seperti pada penelitian ini misalnya, siswa mampu dengan baik memikirkan dan menimbang bahwa disiplin yang dibuat oleh sekolah adalah untuk kebaikan diriya.Menurut Ghufron, N.M. dan Risnawati, R. (2010) bahwa kemampuan untuk menilai keadaan dapat dilakukan dengan memperhatikan segi positif-negatifnya secara subjektif.

Menurut Averill (dalam Syamsul Bachri, 2010) kontrol kognitif merupakan kemampuan seseorang dalam mengolah informasi yang diinginkan atau tidak diinginkan dengan cara menginterpretasi, menilai, atau menggabungkan suatu kejadian dalam suatu kerangka kognitif sebagai adaptasi psikologis atau untuk mengurangi tekanan. Individu yang memilki kontrol kognitif yang tinggi akan mampu mengolah informasi dari suatu peristiwa yang diperolehnya dan menilai situasi tersebut. Jika informasi yang diperoleh akan menimbulkan kondisi yang tidak menyenangkan maka individu dapat melakukan antisipasi agar tidak terjadi masalah.

Dengan demikian, kontrol kognitif siswa di SMK N 1 Kotanopan dalam hal memperoleh informasi dan melakukan penilaian terhadap suatu disiplin di sekolah perlu ditingkatkan dari kategori cukup baik dan baik menjadi sangat baik. Peningkatan kontrol kognitif siswa dalam melaksanakan disiplin di sekolah dapat ditingkatkan melalui layanan bimbingan dan konseling.

\section{Gambaran Kontrol Keputusan Siswa dalam Melaksanakan Disiplin di Sekolah}

Berdasarkan temuan penelitian, terungkap sebagian besar siswa memiliki kemampuan mengontrol keputusan dalam melaksanakan disiplin di sekolah tergolong pada kategori "kurang baik dan tidak baik" dengan capaian responden $35,5 \%$.

Hal ini berarti masih terdapat sebagian siswa yang kurang baik dalam mengambil keputusan yang ada. Seperti pada penelitian ini, masih ada siswa yang tergesa-gesa dalam mengambil suatu keputusan ataupun salah 
dalam mengambil keputusan. Misalnya, masih terdapat siswa yang tidak mematikan hanphone saat jam pelajaran berlangsung, juga masih ada siswa yang menunda-nunda dalam mengerjakan PR.

Menurut Averill (dalam Sari, L., 2014) kontrol keputusan merupakan kemampuan individu untuk memilih tindakan berdasarkan pada sesuatu yang diinginkannya atau setuju dengan tindakan yang harus diambilnya. Hal ini berfungsi baik dengan adanya suatu kesempatan, kebebasan, atau kemungkinan pada diri individu untuk memilih berbagai kemungkinan tindakan.

Kontrol keputusan yang tinggi akan dimiliki ketika kemampuanya dalam menetukan pilihan berfungsi dengan baik yaitu ketika adanya suatu kesempatan, kebebasan, atau kemungkinan untuk memilih tindakan (Sinaga, R., 2015).

Dengan demikian, kontrol keputusan siswa di SMK N 1 Kotanopan dalam hal mengambil keputusan sangat perlu ditingkatkan dari kategori kurang baik menjadi sangat baik. Peningkatan kontrol keputusan siswa dalam melaksanakan disiplin di sekolah dapat ditingkatkan melalui layanan bimbingan dan konseling.

\section{Gambaran Kontrol Diri Siswa dalam Melaksanakan Disiplin di Sekolah secara Keseluruhan}

Berdasarkan hasil penelitian secara keseluruhan, terungkap sebagian besar siswa memiliki kontrol diri "baik" dalam melaksanakan disiplin di sekolah dengan capaian responden $35,5 \%$. Hal ini menunjukkan siswa di SMK N 1 Kotanopan memiliki kontrol diri yang baik melaksanakan disiplin di sekolah. Namun hal ini masih sangat perlu ditingkatkan karena dari hasil penelitian juga ditemukan bahwa masih ada siswa yang memilki kontrol diri yang kurang baik dalam melaksanakan disiplin yaitu 34,8\%.

Menurut Berk (dalam Suyasa, 2006) kontrol diri adalah kemampuan individu untuk menahan keinginan atau dorongan sesaat yang bertentangan dengan tingkah laku yang tidak sesuai dengan norma sosial. Kontrol diri juga disebutkan sebagai kemampuan untuk membimbing tingkah laku sendiri, kemampuan untuk menekan atau merintangi impuls-impuls dan tingkah laku impulsif (Chaplin, 2009).

Selanjutnya Bauimester (dalam Sari, L., 2014) mengemukakan bahwa kontrol diri mengacu pada kecakapan untuk mengubah atau mengarahkan setiap respon individu, baik pikiran, emosidan tindakan secara sadar, terutama mengendalikan impuls dan melawan segala yang menggangu pikiran.

Berdasarkan pendapat tersebut, sangat dibutuhkan usaha untuk dapat meningkatkan kondisi kontrol diri siswa dengan memberikan layanan-layanan konseling. Adapun layanan yang dapat diberikan yaitu layanan informasi, layanan konseling perorangan dan layanan bimbingan kelompok.

\section{Implikasi dalam Layanan Bimbingan dan Konseling}

Guru BK/konselor dapat memberikan beberapa layanan yang sesuai dengan kondisi dan kebutuhan siswa sebagai upaya meningkatkan kontrol diri siswa dalam menerapkan disiplin di sekolah. Layanan tersebut adalah sebagai berikut:

\section{Layanan Informasi}

Menurut Syamsu Yusuf L.N dan A. Juntika Nurihsan (2011) "layanan informasi merupakan penyajian informasi dalam arti menyajikan keterangan (informasi) tentang berbagai aspek kehidupan yang diperlukan individu". Hal ini sesuai dengan pendapat Prayitno (2012) yang menyebutkan bahwa layanan informasi adalah layanan yang berusaha memenuhi kekurangan individu akan informasi yang mereka perlukan. Dalam layanan ini, kepada peserta layanan disampaikan berbagai informasi. Informasi itu kemudian diolah dan digunakan oleh individu untuk kepentingan hidup dan perkembangannya. Layanan informasi diselenggarakan oleh guru $\mathrm{BK} /$ konselor yang diikuti oleh seseorang atau lebih peserta.

Materi yang dapat diberikan oleh guru BK/konselor seperti disiplin adalah kunci sukses, pengelolaan emosi yang cerdas, pemberian informasi menyeluruh tentang disiplin yang ada di sekolah.

\section{Layanan Konseling Perorangan}

Konseling perorangan menurut Prayitno (2012) merupakan layanan konseling yang diselenggarakan oleh seorang konselor terhadap klien dalam rangka mengentaskan masalah pribadi klien. Layanan konseling perorangan dapat dilakukan secara langsung maupun tidak langsung. Menurut Syamsu Yusuf L.N dan A. Juntika Nurihsan (2011) "layanan konseling perorangan merupakan layanan terpenting dalam program bimbingan, dimana layanan ini memfasilitasi siswa untuk memperoleh bantuan pribadi secara langsung (face to face)maupun melalui media (telepon atau internet)". 
Menurut Syamsu Yusuf L.N dan A. Juntika Nurihsan (2011) "konseling perorangan memilki dua fungsi penting bagi individu". Pertama, memperoleh pemahaman dan kemampuan untuk mengembangkan kematangan dirinya (aspek potensi kemampuan, emosi, sosial, dan moral-spiritual. Kedua, menanggulangi masalah dan kesulitan yang dihadapinya, baik menyangkut aspek pribadi, sosial, belajar maupun karir.

Dalam konseling perorangan ini, siswa dapat mengutarakan permasalahan yang dialami mengenai disiplin di sekolah dan guru BK/konselor dapat mengarahkan siswa untuk mengambil keputusan yang tepat untuk masalah yang dihadapi sehingga kehidupan efektif siswa sehari-hari dapat tercapai, selain itu guru BK/konselor juga merahasiakan identitas siswa kepada siapapun.

\section{Layanan Bimbingan Kelompok}

Bimbingan kelompok menurut Prayitno (2012) merupakan layanan yang membahas topik-topik umum yang menjadi kepedulian bersama anggota kelompok dengan memanfaatkan dinamika kelompok. Selanjutnya, menurut Dewa Ketut Sukardi (2008) "layanan bimbingan kelompok yaitu layanan bimbingan yang memungkinkan sejumlah peserta didik secara bersama-sama memperoleh berbagai bahan dari narasumber tertentu (terutama dari pembimbing/ konselor) yang berguna untuk menunjang kehidupan sehari-hari baik individu maupun sebagai pelajar, anggota keluarga dan masyarakat serta untuk pertimbangan dalam pengambilan keputusan".

Layanan bimbingan kelompok memiliki tiga fungsi, yaitu: (1) Berfungsi informatif, (2) Berfungsi pengembangan, (3) Berfungsi preventif dan kreatif. Dari pelaksanaan layanan bimbingan kelompok guru BK dapat membahas topik-topik tugas ataupun bebas yang berhubungan dengan kegiatan siswa di sekolah yang berkaitan dengan disiplin.

\section{KESIMPULAN}

Berdasarkan hasil penelitian dan pembahasannya maka dapat disimpulkan bahwa: kontrol diri siswa dalam melaksanakan disiplin di sekolah pada aspek kontrol perilaku berada pada kategori cukup baik, kontrol diri siswa dalam melaksanakan disiplin di sekolah pada aspek kontrol kognitif berada pada kategori cukup baik., kontrol diri siswa dalam melaksanakan disiplin di sekolah pada aspek kontrol keputusan berada pada kategori kurang baik, kontrol diri siswa dalam melaksanakan disiplin di sekolah secara keseluruhan berada pada kategori baik.

Berdasarkan hasil penelitian ini, peneliti mengemukakan beberapa saran, yaitu sebagai berikut: kepada guru BK supaya memberikan pelayanan BK guna meningkatkan konttrol diri siswa dalam melaksanakan disiplin, kepada siswa diharapkan supaya meningkatkan kontrol diri dalam melaksanakan disiplin dan kepada peneliti selanjutnya agar dapat mengungkapkan dan meneliti variabel lain yang berkenaan dengan kontrol diri dan disiplin di sekolah secara mendalam.

\section{DAFTAR RUJUKAN}

Bernardus Widodo. (2013). Perilaku Disiplin Siswa Ditinjau Dari Aspek Pengendalian Diri (Self Control) Dan Keterbukaan Diri (Self Disclosure) Pada Siswa SMK Wonoasri Caruban Kabupaten Madiun. Jurnal Widya Warta. No. 1 Tahun XXXV II/ Januari, 140-151.

Chaplin, J.P. (2009). Kamus Lengkap Psikologi. Jakarta: Rajawali Press.

Dewa Ketut Sukardi. (2008). Pengantar Pelaksanaan Program Bimbingan Dan Konseling Di Sekolah. Jakarta: Rineka Cipta.

M. Nur Ghufron Dan Rini Risnawita. S. (2010). Teori-Teori Psikologi. Yogyakarta: Ar-Ruzz Media.

Nana Sudjana. (2001). Penelitian Dan Penilaian Pendidikan. Bandung: Sinar Baru.

P. Tommy Y.S. Suyasa. (2006). Pengendalian Diri Pada Remaja. Bunga Rampai Psikologi Perkembangan Dari Anak Sampai Usia Lanjut. (Editor: Singgih Gunarsa). Jakarta: Gunung Mulia.

Prayitno. (2012). Jenis Layanan Dan Kegiatan Pendukung Konseling. Padang: BK FIP UNP.

Sari, L. (2014). Pengaruh Kontrol Diri Terhadap Perilaku Cyberloafing Pada Pegawai Perpustakaan. Skripsi. Tidak Diterbitkan. Medan: USU.

Sinaga, R. (2015). Perbedaan Kontrol Diri Pada Remaja Yang Berasal Dari Keluarga Utuh Dan Keluarga Bercerai. Skripsi. Tidak Diterbitkan. Medan: USU.

Soejitni Irmin Dan Abdul Rochim. (2004). Membangun Disiplin Diri Melalui Kecerdasan Spiritual Dan Emosional. Jakarta: Batavia Press. 
Sofan Amri. (2013). Pengembangan Dan Model Pembelajaran Dalam Kurikulum 2013. Jakarta: Prestasi Pustakarya.

Syamsu Yusuf L.N Dan A. Juntika Nurihsan. (2011). Landasan Bimbingan \& Konseling. Bandung: PT. Remaja Rosdakarya.

Syamsul Bachri Thalib. (2010). Psikologi Pendidikan Berbasis Analisis Empiris Aplikatif. Jakarta: Prenada Media Group.

Zulkarnain. (2002). Hubungan Kontrol Diri Dengan Kreativitas Pekerja. Tesis. Tidak Diterbitkan. Medan: Fakultas Kedokteran Universitas Sumatera Utara. 